\title{
Banks of microscopic forms and survival to darkness of propagules and microscopic stages of macroalgae
}

\author{
Bancos de formas microscópicas y supervivencia a la oscuridad de propágulos y \\ formas microscópicas de macroalgas
}

BERNABÉ SANTELICES, DIEGO AEDO \& ALICIA HOFFMANN

Departamento de Ecología, Facultad de Ciencias Biológicas, Pontificia Universidad Católica de Chile, Casilla 114-D, Santiago, Chile; e-mail: bsanteli@genes.bio.puc.cl

\begin{abstract}
Previous studies have found that the number of species conforming a bank of microscopic forms in tide pools in central Chile accounted only for half the number of species present in the macroscopic vegetation around the pools. An elemental condition for survival in these banks is the ability of microscopic forms to tolerate darkness or very low irradiances for extended periods. To test this ability, spores of 17 green, brown and red algal species, present and absent from the bank, were incubated at different combinations of irradiances and day lengths. Propagules of $47 \%$ of the species tested (eight species) germinated in total darkness while the propagules of the other nine species germinated under conditions of very low irradiance $\left(2-10 \mu \mathrm{mol} \mathrm{m}^{-2} \mathrm{~s}^{-1}\right)$. In most species, microforms showed a higher tolerance to darkness than the propagules. Some survived for over a year and one species (Gelidium lingulatum) could live under complete darkness for 500 days. The ability to survive in total darkness did not relate to presence or absence of a species in the banks of microscopic forms previously studied, to phylogenetic relatedness, life history style, propagule size, morphology of microscopic forms or to successional status (fugitive versus late successional). Thus, tolerance to darkness appears to be common to propagules and microscopic stages of most benthic algae. The growth patterns exhibited by the microforms of Lessonia nigrescens, Chaetomorpha firma and Glossophora kunthii suggest high irradiances on these recruits might determine the shallower limits of distribution of these species.
\end{abstract}

Key words: benthic algae, dark tolerance, germination, growth, microscopic forms.

\section{RESUMEN}

Estudios previos han encontrado que el número de especies formando un banco de formas microscópicas en pozas de mareas de Chile central incluyó sólo la mitad del número de especies presentes en la vegetación macroscópica en las cercanías de las pozas intermareales. Una primera condición para sobrevivir en estos bancos radica en la capacidad de las formas microscópicas para tolerar oscuridad total o baja iluminación por períodos prolongados. Para evaluar dicha capacidad, los propágulos de 17 especies de algas verdes, pardas y rojas, presentes y ausentes del banco de formas microscópicas fueron incubadas a distintas combinaciones de intensidad luminosa y fotoperíodo. Propágulos del $47 \%$ de las especies evaluadas (ocho especies) germinaron en oscuridad mientras que los propágulos de las otras nueve especies requirieron valores muy bajos de intensidad luminosa $\left(2-10 \mu \mathrm{mol} \mathrm{m}^{-2} \mathrm{~s}^{-1}\right)$ para germinar. En una mayoría de las especies, las formas microscópicas mostraron una mayor tolerancia a la oscuridad que los propágulos. Algunos sobrevivieron en la oscuridad por sobre un año y una especie (Gelidium lingulatum) pudo sobrevivir en oscuridad absoluta por 500 días. La habilidad para sobrevivir en oscuridad total no se relaciona con presencia de la especie en los bancos de formas microscópicas, con grupos filogenéticos o con historias de vida específicas, con tamaño de propágulo, morfología de la forma microscópica o estatus sucesional (especies fugitivas versus sucesionales tardías). Por lo tanto, tolerancia a la oscuridad aparece como un patrón común a propágulos y formas microscópicas de una mayoría de algas bentónicas. Los patrones de crecimiento exhibidos por las formas microscópicas de Lessonia nigrescens, Chaetomorpha firma y Glossophora kunthii sugiere que el efecto de altas intensidades luminosas sobre estos reclutas podría determinar los límites superiores de distribución vertical de estas especies.

Palabras clave: algas bentónicas, crecimiento, germinación, formas microscópicas, tolerancia a la oscuridad.

\section{INTRODUCTION}

Rocky intertidal and shallow subtidal habitats often contain collections of microscopic algal forms that under adequate environmental conditions would eventually develop into macroalgal vegetation. These "banks of microscopic forms" (sensu Chapman 1986) are expected to be most 
common in disturbed habitats (Santelices 1990), including environments with high rates of substratum turn-over or high grazing pressure.

Recent experimental studies on the bank of microscopic forms suggest that in various habitats these microforms may determine the presence of the macroscopic vegetation (e.g., Macrocystis, Desmarestia, Graham 1996, Ladah et al. 1999, Edwards 2000), enhance seasonal recruitment (Edwards 2000), determine interspecific differences in population dynamics (Lotze et al. 1999, 2000, Lotze \& Schramm 2000, Worm et al. 2000) and, together with grazers, even determine the capacity of some of these systems to use anthropogenic nutrient loading (Worm et al. 2000).

While characterizing an assemblage of microscopic forms in tide pools from central Chile, Santelices et al. (1995) found that the 25 species conforming the bank amounted only to half the number of species present in the macroscopic vegetation around the bank. The unrepresented species could be missing from the bank because they have not arrived to the bank or because they lack the physiological capacity to survive in these banks. A first condition necessary for survival in the banks relates to the ability of these microscopic forms to tolerate darkness or dim light for extended periods. Propagules and microscopic forms of Laminariales and a few red and green algae have been found to be able to survive in darkness or in very dim light (Burrows 1958, Kain 1964, Neushul \& Dahl 1964, Chapman \& Burrows 1970, Lünning 1980, Schonbeck \& Norton 1980, Hay \& Norris 1984, Reed et al. 1992, tom Dieck 1993, Leukart \& Lünning 1994, Schories 1995). However, it is unknown whether this capacity is general to all types of microscopic forms of macroalgae. Therefore, in this study we first evaluate the ability of seaweed propagules to germinate and of microforms to survive in darkness, comparing such a response in species represented with that of species unrepresented in the banks of microscopic forms described for tide pools in central Chile.

In some species (e.g., Macrocystis pyrifera Graham 1996) the sensitivity of microforms to high levels of irradiance may determine the upper vertical limits of the macroforms distribution on the shore. Therefore, in this study we also evaluate the sensitivity of the microscopic forms to various light levels by measuring growth patterns of algal microforms under controlled laboratory conditions of light intensity and photoperiod.

Little is known about the dynamics of microforms or the types of seaweeds for which a bank of microscopic forms might provide greater survivorship of the species (see review by Hoffmann \& Santelices 1991). Among land plants, early successional pioneering species usually contribute to seed banks more than late successional species (Harper 1977, Grime 1979, Leck et al. 1989). Therefore, we also investigated: if differences in the duration of survival are related to the successional position of the species, if responses are related to the life history of the species, if microforms of similar morphologies have similar responses, and if different responses of microforms are related to the species phylogenetic position (e.g., Phaeophyta, Chlorophyta, Rhodophyta).

\section{MATERIAL AND METHODS}

\section{Habitat characteristics}

All algal samples were collected at Los Molles $\left(32^{\circ} 46^{\prime} \mathrm{S}, 71^{\circ} 33^{\prime} \mathrm{W}\right)$ in central Chile between April and December 1997. In that locality, daylength fluctuates from $10.5 \mathrm{~h}$ in June (austral winter) to $16 \mathrm{~h}$ in December (austral summer). Average surface water temperature ranges from $12.5^{\circ} \mathrm{C}$ in August to $15^{\circ} \mathrm{C}$ in January (Prado \& Sievers 1987, Santelices 1991). Irradiance values measured at rocky surfaces vary from $1500 \pm 300$ $\mu \mathrm{mol} \mathrm{m} \mathrm{s}^{-2}$ in January to $600 \pm 200 \mu \mathrm{mol} \mathrm{m} \mathrm{m}^{-2} \mathrm{~s}^{-1}$ in July. The corresponding values for micro-habitats such as $5-10 \mathrm{~cm}$ deep rocky crevices or underneath the Lessonia canopy was 0.5 to $3.0 \pm 0.5 \mu \mathrm{mol} \mathrm{m}$ ${ }^{2} \mathrm{~S}^{-1}$ (measured with a LAMBDA Quantum/ Radiometer/Photometer LI-COR 185A).

\section{General culture conditions}

After collection, samples were placed in individual plastic bags and carried to the laboratory in refrigerated containers. Spores were obtained using the dehydration method. Spores were then placed in Petri dishes $(50 \times 10 \mathrm{~mm})$ containing SWM-3 culture solution (McLachlan 1973) and incubated in growth chambers under controlled conditions of irradiance $(0,2,10,25,50,75$ and $\left.100 \mu \mathrm{mol} \mathrm{m}^{-2} \mathrm{~s}^{-1}\right)$, daylength $(8,12$ and $16 \mathrm{~h}$ of daily light) and temperature $\left(15^{\circ} \mathrm{C}\right)$. The culture medium was changed every six days. Change of culture medium under $0 \mu \mathrm{mol} \mathrm{m} \mathrm{m}^{-2} \mathrm{~s}^{-1}$ was aided with a $5 \mu \mathrm{mol} \mathrm{m}^{-2} \mathrm{~s}^{-1}$ red light lamp. Each individual culture was exposed between 20 and 40 s to this irradiance source during the change of culture medium. 
Specific experimental conditions: ability to germinate in total darkness and minimum light requirement for germination

The ability of seaweed propagules to germinate in darkness and the minimum light requirement for germination were determined for a total of 17 species. Seven of these (Enteromorpha compressa, E. intestinalis, Ulva rigida, Ectocarpus confervoides, Hincksia mitchelliae, Gelidium lingulatum and Mazzaella laminarioides) have been previously found in the banks of microscopic forms (Santelices et al. 1995), while the other 10 species (Chaetomorpha firma, C. linum, Adenocystis utricularis, Endarachne binghamiae, Scytosiphon lomentaria, Glossophora kunthii, Lessonia nigrescens, Montemaria horridula, Centroceras clavulatum and Chondrus canaliculatus) had not been found in the bank.

Six replicate dishes each containing spores of one of the above species were incubated under each combination of irradiance and photoperiod for all 17 species listed above. Total darkness was obtained by placing the culture dishes into lighttight boxes. Absence of light was confirmed using a light sensor (LI-COR 185A). After 4 days of incubation, the presence of germinating spores was determined by examining 10 microscopic fields in three of the culture dishes from each treatment. Germination was judged positive when at least $25 \%$ of the alive spores found in the microscopic field exhibited germination. Since ungerminated spores normally became paler and suffered cell lysis, exact counts of germination frequency (or germination rate) could not be obtained. A second evaluation of germination under each combination of irradiance and photoperiod in darkness was completed after six days of incubation, using the remaining three replicate Petri dishes per treatment. In the case of Ectocarpus confervoides, evaluation of germination in darkness was repeated with a larger number (24) of replicates. After 6 days, evaluations were repeated weekly, for up to 8 weeks.

The relationship between the ability to survive in darkness and the presence or absence of the species in the bank of microscopic forms was analyzed using chi-square test (Sokal \& Rohlf 1981).

Specific experimental conditions: ability of the microscopic forms to survive in darkness and their growth rate under different irradiances

To evaluate the ability of the microscopic forms to survive in darkness, a subsample of 15 species was used (all the above except Chaetomorpha linum and Centroceras clavulatum). This combination of species included microscopic forms with different morphologies (germling-like, filaments and discs), differential tolerance to germination in darkness and differential presence in the banks of microscopic forms. A total of 60 to 80 Petri dishes per species, with germinated spores and 6 day-old microscopic forms were placed in light-tight boxes. Three dishes were removed from darkness at monthly intervals, from which the microscopic forms were examined for pigmentation and then incubated for 15 days under optimal light conditions to evaluate their recovery capacity. In the cases of Chondrus canaliculatus and Mazzaella laminarioides, evaluation was done weekly. In the case of Enteromorpha compressa and Gelidium lingulatum, the total number of replicate dishes used were 150 and 200 , respectively.

The growth rates of the various microforms under various irradiances and photoperiods were measured using three replicate culture dishes incubated under each combination of irradiance and daylength described above. Growth of microscopic forms was determined weekly for up to 21 days. The area of crustose germlings was measured from outline drawings made with a drawing mirror on a Wild microscope; the length of filamentous forms was measured with a micrometer. Mean values were calculated from measurements of 30 microscopic forms (10 in each replicate dish) and compared using a two-way ANOVA followed by a posteriori Tukey's tests (Sokal \& Rohlf 1981). Spore abundance not always was enough for the 21 treatments used. In those cases a few intermediate treatments were omitted (e.g., normal day regimes in Enteromorpha compressa or Scytosiphon lomentaria).

\section{RESULTS}

\section{Ability to germinate in total darkness}

Propagules of eight of the 17 species tested (47\%) germinated under total darkness, while propagules of the remaining nine species did not germinate in darkness (Table 1). Among these, the zooids of Ectocarpus confervoides could survive without germination under total darkness for up to 45 days, after which they became colorless and died. Propagules of the other eight species under 0 $\mu \mathrm{mol} \mathrm{m} \mathrm{m}^{-2}$ became colorless and died within 48$96 \mathrm{~h}$.

The ability to germinate in darkness is unrelated to the presence or absence of these species 
Ability of propagules to germinate in total darkness and relationships to presence in the bank of microscopic forms and to specific characters: $(\mathrm{Z})$ zoospores; (T) tetraspores; (C) carpospores; (E) ephemeral; (P) perennial

Capacidad de los propágulos para germinar en oscuridad y relación con su presencia en el banco de formas
microscópicas y con caracteres específicos; $(\mathrm{Z})$ zoosporas; $(\mathrm{T})$ tetrasporas; (C) carposporas; (E) efímeras; (P)
perennes

\begin{tabular}{|c|c|c|c|c|c|c|}
\hline Species & $\begin{array}{c}\text { Presence in } \\
\text { the bank of } \\
\text { microscopic forms }\end{array}$ & $\begin{array}{l}\text { Minimum light } \\
\text { requirement for } \\
\text { germination } \\
\left(\mu \mathrm{mol} \mathrm{m}-2 \mathrm{~s}^{-1}\right)\end{array}$ & $\begin{array}{c}\text { Propagule } \\
\text { type }\end{array}$ & $\begin{array}{l}\text { Propagule } \\
\text { diameter } \\
\quad(\mu \mathrm{m})\end{array}$ & $\begin{array}{l}\text { Life history } \\
\text { type }\end{array}$ & $\begin{array}{c}\text { Successional } \\
\text { status }\end{array}$ \\
\hline
\end{tabular}

Chlorophyta

Chaetomorpha firma Levring

Chaetomorpha linum (Müller) Kützing

Enteromorpha compressa (Linnaeus) Greville

Enteromorpha intestinalis (Linnaeus) Link

Ulva rigida C. Agardh

Phaeophyta

Ectocarpus confervoides (Roth) Le Jolis

Adenocystis utricularis (Bory) Skottsberg

Endarachne binghamiae J. Agardh

Hincksia mitchelliae (Harvey) Silva

Scytosiphon lomentaria (Lyngbye) J. Agardh

Glossophora kunthii (C. Agardh) J. Agardh

Lessonia nigrescens Bory

Rhodophyta

Montemaria horridula (Montagne) Joly \& Alveal

Centroceras clavulatum (C. Agardh) Montagne

Chondrus canaliculatus (C. Agardh) Greville

Gelidium lingulatum Kützing

Mazzaella laminarioides (Bory) Fredericq

No
No
Yes
Yes
Yes

0
0
0
0
5

$\mathrm{Z}$
$\mathrm{Z}$
$\mathrm{Z}$
$\mathrm{Z}$
$\mathrm{Z}$

10.7
10.0
4.0
5.2
9.9

$\begin{array}{ll}\text { Isomorphic } & \mathrm{P} \\ \text { Isomorphic } & \mathrm{E} \\ \text { Isomorphic } & \mathrm{E} \\ \text { Isomorphic } & \mathrm{E} \\ \text { Isomorphic } & \mathrm{E}\end{array}$

$\begin{array}{lccccc}\text { Yes } & 2-5 & \mathrm{Z} & 4.2 & \text { Isomorphic } & \mathrm{E} \\ \text { No } & 2-5 & \mathrm{Z} & 7.5 & \text { Heteromorphic } & \mathrm{E} \\ \text { No } & 10 & \mathrm{Z} & 5.6 & \text { Isomorphic } & \mathrm{E} \\ \text { Yes } & 2-5 & \mathrm{Z} & 3.7 & \text { Isomorphic } & \mathrm{E} \\ \text { No } & 2-5 & \mathrm{Z} & 18.0 & \text { Heteromorphic } & \mathrm{E} \\ \text { No } & 0 & \mathrm{Z} & 28.0 & \text { Isomorphic } & \mathrm{P} \\ \text { No } & 0 & \mathrm{Z} & 5.7 & \text { Heteromorphic } & \mathrm{P}\end{array}$

\begin{tabular}{ccccll} 
No & 0 & T & 22 & Isomorphic & P \\
No & 0 & T & 26 & Isomorphic & E \\
No & $2-5$ & T & 25 & Isomorphic & P \\
Yes & $2-5$ & C & 29 & Isomorphic & P \\
Yes & $2-5$ & C & 25 & Isomorphic & P \\
\hline
\end{tabular}

in the banks of microscopic forms $\left(\chi^{2}=1.63, \mathrm{P}=\right.$ $0.2014)$. Only two of the seven species found in the bank were able to germinate in total darkness, while the other five required a minimum irradiance of $2-5 \mu \mathrm{mol} \mathrm{m}^{-2} \mathrm{~s}^{-1}$ to germinate. On the other hand, six other species absent from the bank of microscopic forms were able to germinate in darkness (e.g., C. firma, C. linum, G. kunthii, $L$. nigrescens, M. horridula, C. clavulatum).

The relative representation of species with ability to germinate under total darkness within each major algal Division seems to be unequal. Germination under darkness appears most abundant among Chlorophyta and least abundant among Phaeophyta. However, the number of species tested is small and the tendency could change with larger sample sizes.

No relationship was found between the ability to germinate in darkness and some propagule characteristics such as propagule diameter (Table 1), presence or absence of flagella, life history of the species (isomorphic/heteromorphic) or successional status. Propagules of four species regarded as fugitive (Chaetomorpha linum, Enteromorpha compressa, E. intestinalis and Centroceras clavulatum) as well as those of four late successional (Chaetomorpha firma, Glossophora kunthii, Lessonia nigrescens, Montemaria horridula) exhibit the ability to germinate in total darkness.

\section{Minimum light requirement for germination}

With the exception of Endarachne binghamiae, all species that could not germinate under total darkness could do so under irradiances as low as 2-5 $\mu \mathrm{mol} \mathrm{m} \mathrm{m}^{-2} \mathrm{~s}^{-1}$ (Table 1). Germination of $E$. binghamiae needed irradiance values equal or above $10 \mu \mathrm{mol} \mathrm{m} \mathrm{m}^{-2} \mathrm{~s}^{-1}$. 
Ability of the microscopic forms to survive in darkness

The microscopic forms of 13 of the 15 species tested $(86.7 \%)$ were able to survive in total darkness (Table 2). Maximum survival time for the dark-tolerant species was 500 days (germlings of Gelidium lingulatum) and the minimum was 60 days (crustose microforms of Scytosiphon lomentaria). These microscopic forms did not grow while in darkness, but did so when transferred to light.

The ability of microforms to survive in darkness is widespread among species previously found as well as among those not found in the banks of microscopic forms in boulder fields (Table 2) and also among the three major Divisions of benthic algae, among different types of morphologies (germlings, cell filaments or discs), life history types and successional status. Only the juvenile discs of two red algal species (Chondrus canaliculatus and Mazzaella laminarioides) did not tolerate darkness for more than a few (57) days.
Growth rates of microforms under different irradiances

The growth rates exhibited by the microforms under the various combinations of irradiance and daylength tested (Fig. 1, Table 3) indicated a diversity of responses. Species such as Ulva rigida, E. confervoides, A. utricularis, $G$. lingulatum and M. laminarioides exhibit little growth under either low irradiances, short photoperiods or both. In these species, increasing growth rates are exhibited with increasing irradiances or longer photoperiods. On the other hand, the microforms of species such as Scytosiphon lomentaria and, to a lesser extent, Enteromorpha compressa grew equally well under most of the laboratory conditions tested (Fig. 1, Table 3), while the microscopic stages of Chaetomorpha firma, Glossophora kunthii and Lessonia nigrescens did not grow at the higher irradiances tested $\left(100 \mu \mathrm{mol} \mathrm{m} \mathrm{m}^{-2} \mathrm{~s}^{-1}\right)$. The germlings of $C$. firma were the most light sensitive (Fig. 1) as they grew best under irradiances between 2 and $25 \mu \mathrm{mol} \mathrm{m} \mathrm{m}^{-2} \mathrm{~s}^{-1}$. They were unable to tolerate 75

TABLE 2

Number of days microscopic forms of macroscopic algae could survive in total darkness and relationships of survival in darkness to other characteristics of the species; (E) ephemeral; (P) perennial

Número de días que las formas microscópicas de algas macroscópicas pueden sobrevivir en completa oscuridad y las relaciones entre capacidad para sobrevivir en la oscuridad y otras características de la especie; (E) efímeras; (P) perennes

\begin{tabular}{|c|c|c|c|c|}
\hline Species & $\begin{array}{c}\text { Presence } \\
\text { in the bank of } \\
\text { microscopic forms }\end{array}$ & $\begin{array}{l}\text { Survival time in } \\
\text { total darkness } \\
\text { (days) }\end{array}$ & $\begin{array}{l}\text { Morphology } \\
\text { of the } \\
\text { microform }\end{array}$ & $\begin{array}{c}\text { Successional } \\
\text { status }\end{array}$ \\
\hline
\end{tabular}

Chlorophyta

Chaetomorpha firma

Enteromorpha intestinalis

Ulva rigida

Enteromorpha compresa

Phaeophyta

Ectocarpus confervoides

Hincksia mitchelliae

Adenocystis utricularis

Endarachne binghamiae

Scytosiphon lomentaria

Glossophora kunthii

Lessonia nigrescens

Rhodophyta

Montemaria horridula

Gelidium lingulatum

Chondrus canaliculatus

Mazzaella laminarioides
No

Yes

Yes

Yes

Yes

Yes

No

No

No

No

No

$\begin{array}{lc}\text { No } & 90 \\ \text { Yes } & 500 \\ \text { No } & 5 \\ \text { Yes } & 5\end{array}$

120
397

190

225

266

70

60

225

90
Germling

Germling

Germling

Germling

P

E

E

$\begin{array}{cc}\text { Filament } & \text { E } \\ \text { Filament } & \text { E } \\ \text { Disc } & \text { E } \\ \text { Disc } & \text { E } \\ \text { Disc } & \text { E } \\ \text { Germling } & P \\ \text { Filament } & P\end{array}$

$\begin{array}{cl}\text { Germling } & \mathrm{P} \\ \text { Germiling } & \mathrm{P} \\ \text { Disc } & \mathrm{P} \\ \text { Disc } & \mathrm{P}\end{array}$



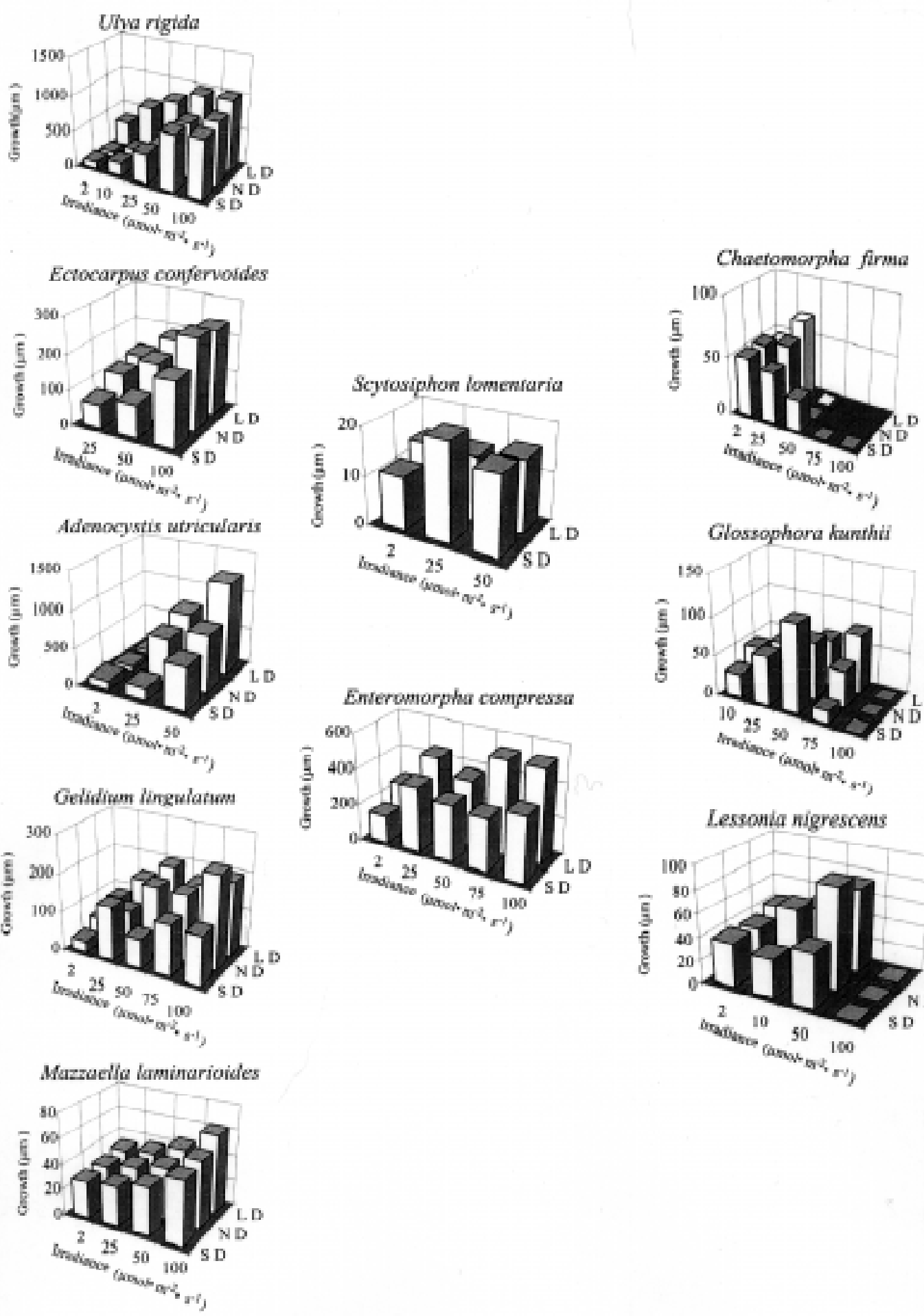

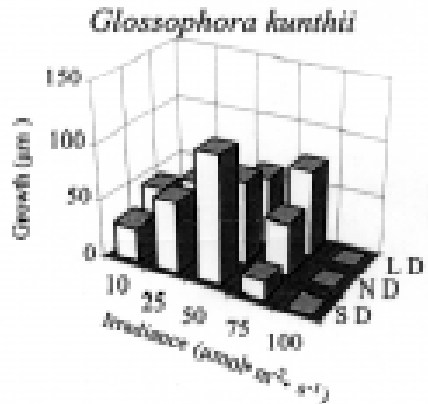

Lessonia nigrescens

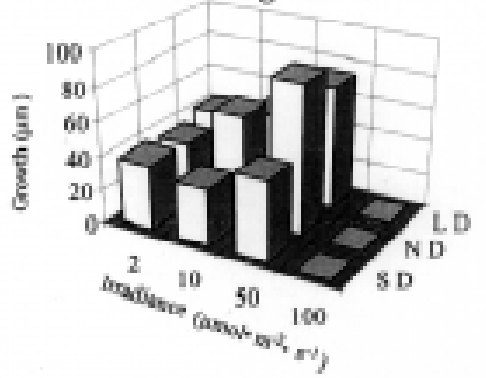

Fig. 1: Interactiv effects of irradiance $\left(\mu \mathrm{mol} \mathrm{m} \mathrm{m}^{-2} \mathrm{~s}^{-1}\right)$ and daylength on the growth of microscopic forms of macroscopic algae. Key to abbreviations of daylength: (SD) short day; (ND) normal day; (LD) long day.

Efectos interactivos de irradiación y longitud del día en el desarrollo de formas microscópicas de algas bentónicas. Clave de las abreviaciones de longitud del día: (SD) día corto; (ND) día normal; (LD) día largo. 
The effects of photon fluence rate and photoperiod on the growth rate of microscopic forms. For each condition, values sharing same letter are not significantly different $(\mathrm{P}<0.05$, Tukey test); (SD) = short day; (ND) normal day; (LD) long day; (P x PF) photoperiod x photon flux interaction

Los efectos de flujo fotónico y fotoperíodo sobre el crecimiento de las formas microscópicas. Para cada condición, los valores compartiendo una misma letra no son significativamente diferentes ( $\mathrm{P}<0,05$; prueba de Tukey); (SD) día corto; (ND) día normal; (LD) día largo; (P x PF) interacción fotoperíodo x flujo fotónico

\begin{tabular}{|c|c|c|c|}
\hline Species & Photoperiod & Photon flux $\left(\mu \mathrm{mol} \mathrm{m} \mathrm{m}^{-2} \mathrm{~s}^{-1}\right)$ & $\begin{array}{l}\text { Photoperiod } \mathrm{x} \\
\text { photon flux }\end{array}$ \\
\hline Ulva rigida & $\mathrm{SD}^{\mathrm{a}}=\mathrm{ND}^{\mathrm{a}}<\mathrm{LD}^{\mathrm{b}}$ & $2^{\mathrm{a}}<10^{\mathrm{b}}<25^{\mathrm{c}}<50^{\mathrm{d}}=100^{\mathrm{d}}$ & Non significant \\
\hline E. confervoides & $\mathrm{SD}^{\mathrm{a}}<\mathrm{ND}^{\mathrm{b}}<\mathrm{LD}^{\mathrm{c}}$ & $25^{\mathrm{a}}<50^{\mathrm{b}}<100^{\mathrm{c}}$ & Significant \\
\hline A. utricularis & $\mathrm{SD}^{\mathrm{a}}<\mathrm{ND}^{\mathrm{b}}<\mathrm{LD}^{\mathrm{c}}$ & $25^{\mathrm{a}}<50^{\mathrm{b}}<100^{\mathrm{c}}$ & Significant \\
\hline G. lingulatum & $\mathrm{SD}^{\mathrm{a}}<\mathrm{ND}^{\mathrm{ab}}<\mathrm{LD}^{\mathrm{b}}$ & $2^{\mathrm{a}}<25^{\mathrm{b}}=50^{\mathrm{b}}=75^{\mathrm{b}}=100^{\mathrm{b}}$ & Non significant \\
\hline M. laminarioides & $\mathrm{SD}^{\mathrm{a}}=\mathrm{ND}^{\mathrm{a}}=\mathrm{LD}^{\mathrm{a}}$ & $2^{\mathrm{a}}=25^{\mathrm{a}}<50^{\mathrm{b}}<100^{\mathrm{c}}$ & Non significant \\
\hline S. lomentaria & $\mathrm{SD}^{\mathrm{a}}=\mathrm{LD}^{\mathrm{a}}$ & $2^{\mathrm{a}}<25^{\mathrm{b}}=50^{\mathrm{b}}$ & Significant \\
\hline E. compressa & $\mathrm{SD}^{\mathrm{a}}<\mathrm{LD}^{\mathrm{b}}$ & $2^{\mathrm{a}}=25^{\mathrm{a}}=50^{\mathrm{a}}=75^{\mathrm{a}}=100^{\mathrm{a}}$ & Non significant \\
\hline C. firma & $\mathrm{LD}^{\mathrm{a}}<\mathrm{ND}^{\mathrm{b}}=\mathrm{SD}^{\mathrm{b}}$ & $100^{\mathrm{a}}=75^{\mathrm{a}}<50^{\mathrm{b}}<25^{\mathrm{c}}=2^{\mathrm{c}}$ & Significant \\
\hline G. kunthii & $\mathrm{LD}^{\mathrm{a}}<\mathrm{ND}^{\mathrm{b}}<\mathrm{SD}^{\mathrm{c}}$ & $100^{\mathrm{a}}<75^{\mathrm{b}}<10^{\mathrm{c}}=25^{\mathrm{c}}<50^{\mathrm{d}}$ & Significant \\
\hline L. nigrescens & $\mathrm{LD}^{\mathrm{a}}=\mathrm{SD}^{\mathrm{a}}<\mathrm{ND}^{\mathrm{b}}$ & $100^{\mathrm{a}}<2^{\mathrm{b}}=10^{\mathrm{b}}<50^{\mathrm{c}}$ & Non significant \\
\hline
\end{tabular}

to $100 \mu \mathrm{mol} \mathrm{m} \mathrm{m}^{-2} \mathrm{~s}^{-1}$ and could tolerate up to 50 $\mu \mathrm{mol} \mathrm{m} \mathrm{m}^{-2} \mathrm{~s}^{-1}$ only when incubated under short day regimes.

\section{DISCUSSION}

Our results confirm the hypothesis that survival in darkness or under dim light is a widespread response among microscopic stages of macroalgae. Propagules of almost half the number of species tested germinated in total darkness, while the remaining species required very low irradiances for germination $\left(2-10 \mu \mathrm{mol} \mathrm{m} \mathrm{m}^{-2} \mathrm{~s}^{-1}\right)$. Similarly, the microforms of 13 of the 15 species tested were able to survive in darkness, some of them with survival time extending 400 (Enteromorpha compressa) and 500 days (Gelidium lingulatum).

The above results agree well with previous literature reports. Under laboratory conditions, spores of several algal species (reviewed in Hoffmann \& Santelices 1991) have been found to be able to germinate under complete darkness, giving rise to microscopic forms. On the other hand, spore survival in darkness without germination, as found in our experiments with Ectocarpus confervoides has also been found in Scytosiphon lomentaria and Ulva pertusa (Whoodhead \& Moss 1975). Similarly, spores of Enteromorpha spp. have been reported to survive more than 10 months in darkness (Schories 1995); those of Laminaria hyperborea survived for 50 days (Kain 1964), while the propagules of Chaetomorpha melagonium and Halarachnion ligulatum survived for up to one year in darkness without germination (Leukart \& Lünning 1994). Regarding the microscopic forms, the gametophytes or the embryos of a total of 16 species have been reported to survive between 2 and 8 months under darkness or very low irradiance conditions (e.g., $1 \mu \mathrm{mol} \mathrm{m} \mathrm{m}^{-2} \mathrm{~s}^{-1}$; see Hoffmann \& Santelices 1991 for data).

The physiological basis for germination not dependent on light are unknown. It has been suggested (Clayton 1992, Reed et al. 1992) that the process is perhaps based on the utilization of polysaccharides and lipid reserves of the propagules. In fact, Brzezinski et al. (1993) observed lipid droplet consumption during spore germination in Macrocystis pyrifera. The availability of light appeared to delay, but did not reduce lipid use. Such carbon and nitrogen reserves could be especially significant in spores and zygotes that settle in dark habitats.

In the case of the microscopic forms, the ability to survive in darkness or dim light could depend on the capacity of the microform to incorporate some of the organic compounds present in the boundary layer, living heterotrophically (Amsler $\&$ Neushul 1991, Amsler et al. 1992, Reed et al. 1992, Fries 1993). Alternatively, the microscopic form could be metabolically active even under very low irradiances. In the case of Desmarestia lingulata, Edwards (2000) found that the over- 
wintering gametophytes were metabolically active and sensitive to changes in environmental quality, being able to photosynthetize even under very low irradiances $\left(8 \mu \mathrm{mol} \mathrm{m} \mathrm{m}^{-2} \mathrm{~s}^{-1}\right)$.

The ability of the spores to germinate in darkness or the survival capacity of the microforms under dark conditions appears unrelated to taxonomic membership, life history style, propagule size or successional status. Microforms of both fugitive and perennial species survived in darkness, suggesting that microforms of species with either strategy have the capacity to function as survival stages in a bank of microscopic forms. Similarly, no relationship was evident between the ability to germinate and survive in darkness and the previous presence of these species in the bank of microscopic forms (Santelices et al. 1995). Absence from the bank may thus be due to other factors, such as short dispersal shadow or low colonization capacity.

The growth patterns of the microforms under various irradiance regimes suggested that three species (C. firma, G. kunthii and Lessonia nigrescens) are sensitive to high irradiances. It is as yet unknown if this sensitivity of the microscopic stage determines any aspect of the spatial distribution of any of these species. However, a similar situation was described by Graham (1996) for Macrocystis pyrifera in California, U.S.A. Using a combination of field and laboratory experiment, Graham (1996) concluded that high irradiance on the recruits regulates the upper vertical limit of $M$. pyrifera prior to the temperature and desiccation stresses inherent to intertidal regions. Perhaps a similar process is occurring with these three above species, which are most abundant in the lowest intertidal-shallow subtidal habitats of central Chile.

\section{ACKNOWLEDGEMENTS}

This study was supported by FONDECYT grants 1930581 and 1990160 . Our appreciation to Randy Finke for improving the grammar.

\section{LITERATURE CITED}

AMSLER CD \& M NEUSHUL (1991) Photosynthetic physiology and chemical composition of spores of the kelps Macrocystis pyrifera, Nereocystis lutkeana, Laminaria farlowii and Pterygophora californica (Phaeophyceae). Journal of Phycology 27: 26-34.

AMSLER CD, DC REED \& M NEUSHUL (1992) The microclimate inhabited by macroalgal propagules. British Phycology Journal 27: 253-270.
BRZEZINSKI MA, DC REED \& CD AMSLER (1993) Neutral lipids as major storage products in zoospores of the giant kelp Macroscystis pyrifera (Phaeophyceae). Journal of Phycology 29: 16-23.

BURROWS EM (1958) Subtidal algal population in Port Erin Bay, Isle of Man. Journal of the Marine Biological Association of the United Kingdom 37: 687-703.

CHAPMAN ARO (1986) Population and community ecology of seaweeds. In: Blaxter JHS \& AJ Southwood (eds) Advances in marine ecology: 23:1-161. Academic Press, London, United Kingdom.

CHAPMAN ARO \& EM BURROWS (1970) Experimental investigations into the controlling effects of light conditions on the development and growth of Desmarestia aculeata (L.) Lamour. Phycologia 9: 103-108.

CLAYTON MN (1992) Propagules of marine macroalgae: structure and development. British Phycology Journal 27: 219-232.

EDWARDS MS (2000) The role of alternate life-history stages of a marine macroalga: a seed bank analogue. Ecology 81: 2404-2415.

FRIES L (1993) Vitamin B 12 heterotrophy in Fucus spiralis and Ascophyllum nodosum (Fucales, Phaeophyta) in axenic cultures. Botanica Marina 36: 5-7.

GRAHAM MH (1996) Effect of high irradiance on recruitment of the giant kelp Macrocystis (Phaeophyta) in shallow water. Journal of Phycology 32: 903-916.

GRIME JP (1979) Plant strategies and vegetation processes. John Wiley \& Sons, Chichester, New York. $223 \mathrm{pp}$.

HARPER JL (1977) Population biology of plants. Academic Press, London, United Kingdom. 892 pp.

HAY ME \& JN NORRIS (1984) Seasonal reproduction and abundance of six sympatric species of Gracilaria Grev. (Gracilariaceae; Rhodophyta) on a Caribbean subtidal sand plain. Hydrobiologia 116/117: 63-94.

HOFFMANN AJ \& B SANTELICES (1991) Banks of algal microscopic forms: hypotheses on their functioning and comparisons with seed banks. Marine Ecology Progress Series 78: 71-85.

KAIN JM (1964) Aspects of the biology of Laminaria hyperborea. III. Survival and growth of gametophytes. Journal of the Marine Biological Association of the United Kingdom 44: 415-433.

LADAH LB, JA ZERTUCHE-GONZÁLEZ \& G HERNÁNDEZ-CARMONA (1999) Giant kelp (Macrocystis pyrifera, Phaeophyceae) recruitment near its southern limit in Baja California after mass disappearance during ENSO 1997-1998. Journal of Phycology 35: 1106-1112.

LECK MA, VT PARKER \& RI SIMPSON (1989) Ecology of soil seed banks. Academic Press, San Diego, California. $462 \mathrm{pp}$.

LEUKART P \& K LÜNING (1994) Minimum spectral light requirements and maximum light levels for longterm germling growth of several red algae from different water depths and a green alga. European Journal of Phycology 29: 103-112.

LOTZE HZ, W SCHRAM, D SCHORIES \& B WORM (1999) Control of macroalgal blooms at early developmental stages: Pilayella littoralis versus Enteromorpha spp. Oecologia 119: 46-54. 
LOTZE HK \& W SCHRAMM (2000) Ecophysiological traits explain species dominance patterns in macroalgal blooms. Journal of Phycology 36: 287295.

LOTZE HK, B WORM \& U SOMMER (2000) Propagule banks, herbivory and nutrient supply control population development and dominance patterns in macroalgal blooms. Oikos 89: 46-58.

LÜNING K (1980) Critical levels of light and temperature regulating the gametogenesis of three Laminaria species (Phaeophyceae). Journal of Phycology 16: 1-15.

McLACHLAN J (1973) Growth media-marine. In: Stein JR (ed) Handbook of phycological methods: 25-52. Cambridge University Press, Cambridge, United Kingdom.

NEUSHUL M \& AL DAHL (1967) Composition and growth of subtidal parvosilvosa from Californian kelp forest. Helgoländer wissenchafliche Meeresunters 15: 480488.

PRADO R \& HA SIEVERS (1987) Distribución de características físicas y químicas frente a península Los Molles, Chile (32 $45^{\prime}$ 'S) y su relación con el fenómeno "El Niño" 1982-83. Revista de Biología Marina (Chile) 23: 31-75.

REED DC, CD AMSLER \& AW EBELING (1992) Dispersal in kelps: factors affecting spore swimming and competency. Ecology 73: 1577-1585.

SANTELICES B (1990) Patterns of reproduction, dispersal and recruitment in seaweeds. Oceanography and Marine Biology: An Annual Review 28: 177-276.

SANTELICES B (1991) Littoral and subtidal communities of continental Chile. In: Mathieson AC \& PH Nienhuis (eds) Ecosystems of the world: 24: 347-369. Elsevier, Amsterdam, The Netherlands.
SANTELICES B, AJ HOFFMANN, D AEDO, M BOBADILLA \& R OTAÍZA (1995) The bank of microscopic forms on disturbed boulders and stones in tide pools. Marine Ecology Progress Series 129: 215228.

SCHONBECK MW \& TA NORTON (1980) Factors controlling the lower limits of fucoid algae on the shore. Journal of Experimental Marine Biology and Ecology 43: $131-150$.

SCHORIES D (1995) Sporulation of Enteromorpha spp. (Chlorophyta) and overwintering of spores in sediments of the Wadden Sea, Island Sylt, North Sea. Journal of Aquatic Ecology 29: 341-347.

SOKAL RR \& FJ ROHLF (1981) Biometry. Freeman \& Company, San Francisco, California. 219 pp.

TOM DIECK I (1993) Temperature tolerance and survival in darkness of kelp gametophytes (Laminariales, Phaeophyta): ecological and biogeographical implications. Marine Ecology Progress Series 100: 253254.

VADAS RL, S JOHNSON \& TA NORTON (1992) Recruitment and mortality of early post-settlement stages on benthic algae. British Phycology Journal 27: 331 351.

WOODHEAD P \& B MOSS (1975) The effects of light and temperature on settlement and germination of Enteromorpha. British Phycology Journal 10: 269272.

WORM B, HK LOTZE, C BOSTRÖM, R ENGKVIST, V LABANAUSKAS \& U SOMMER (1999) Marine diversity shift linked to interactions among grazers, nutrients and propagule banks. Marine Ecology Progess Series 185: 309-314. 